\title{
Apice closure in Pulp Revascularization Therapy. Case report and literature review
}

\author{
Fechamento de ápice com a Técnica da Revascularização Pulpar: Relato de caso e revisão de \\ literatura \\ Fechamento de ápice com a Técnica da Revascularização Pulpar: Relato de caso e revisão de
}

literatura

Received: 07/02/2021 | Reviewed: 07/09/2021 | Accept: 07/14/2021 | Published: 08/03/2021

\author{
Hadassa Fonsêca Da Silva \\ ORCID: https://orcid.org/0000-0002-9432-9522 \\ Faculdade de Odontologia do Recife, Brazil \\ E-mail: hadassafonseca1@gmail.com \\ Alice Pinho André Gomes Morais \\ ORCID: https://orcid.org/0000-0001-9008-4196 \\ Faculdade de Odontologia do Recife, Brazil \\ E-mail: alicepinho@globo.com \\ Guilherme Marinho Sampaio \\ ORCID: https://orcid.org/0000-0003-4441-7601 \\ Faculdade de Odontologia do Recife, Brazil \\ E-mail: guilhermemarinhosampaio@gmail.com \\ Gabriel Henrique Queiroz Oliveira \\ ORCID: https://orcid.org/0000-0002-7795-3964 \\ Faculdade de Odontologia do Recife, Brazil \\ E-mail: qgabriel116@gmail.com \\ Paulo Melo Júnior \\ ORCID: https://orcid.org/0000-0001-9926-5348 \\ Faculdade de Odontologia do Recife, Brazil \\ E-mail: paulo.reis@upe.br \\ Sandra Sayão Maia \\ ORCID: https://orcid.org/0000-0001-6808-9775 \\ Faculdade de Odontologia do Recife, Brazil \\ E-mail: sandrinhasayao@hotmail.com \\ Luciano Barreto Silva \\ ORCID: https://orcid.org/0000-0002-1508-4812 \\ Faculdade de Odontologia do Recife, Brazil \\ E-mail: lucianobarreto63@gmail.com
}

\begin{abstract}
Background: Endodontic Regenerative Procedures, especially pulp revascularization therapy, have become a real option for the treatment for immature permanent teeth with open apices. This sort of approach has saved many teeth that otherwise would have been extracted. The technique is simple and effective, and can be accomplished by any odontologist. Objective: This article aimed to make a literature review to give support for a case report of an Endodontic Regenerative Procedure of a twelve-year-old male patient with immature open apice of tooth 21 . Methodology: Articles were researched concerning pulp revascularization to reach root end formation. On line searches were accomplished, whose database include BVS/BIREME, Web of Science, PUBMED Central, Science Direct, Higher Level Personnel Improvement Coordinator (CAPES), The Cochrane Library, and PROSPERO). Results: the articles researched showed that Endodontic Regenerative Procedures are efficient in stimulating root end formation. The case report described matched the results offered by the articles, showing an immature open apice tooth that had its root end completely formed after pulp revascularization therapy. Conclusion: Pulp revascularization therapy is an efficient and practical treatment for immature teeth with open apices.
\end{abstract}

Keywords: Endodontics; Calcium hydroxide; Blood vessels; MTA; Stem cells; Therapeutics.

\section{Resumo}

Background: Os procedimentos endodônticos regenerativos, principalmente a terapia de revascularização pulpar, têm se tornado uma opção real para o tratamento de dentes permanentes imaturos com ápices abertos. Esse tipo de abordagem salvou muitos dentes os quais, de outra forma, teriam sido extraídos. A técnica é simples e eficaz, podendo ser realizada por qualquer odontólogo clínico. Objetivo: Este artigo teve como objetivo fazer uma revisão da literatura para dar suporte a um relato de caso de uma Procedimento Endodôntico Regenerativo em um paciente do sexo masculino de 12 anos de idade com ápice aberto do elemento dentário imaturo 21. Metodologia: Foram pesquisados artigos sobre Revascularização Pulpar para a obtenção da formação completa da raiz. Foram realizadas buscas on-line, 
cujas bases de dados incluem BVS/BIREME, Web of Science, PUBMED Central, Science Direct, Coordenador de Aperfeiçoamento de Pessoal de Nível Superior (CAPES), The Cochrane Library e PROSPERO. Resultados: os artigos pesquisados mostraram que os Procedimentos Endodônticos Regenerativos são eficientes no estímulo à formação da porção radicular terminal. O relato de caso descrito condiz com os resultados oferecidos pelos artigos, mostrando um dente apical imaturo aberto que teve sua extremidade radicular completamente formada após a terapia de revascularização pulpar. Conclusão: A terapia de revascularização pulpar é um tratamento eficaz e prático para dentes imaturos com ápices abertos.

Palavras-chave: Endodontia; Hidróxido de cálcio; Vasos sanguíneos; MTA; Células-tronco; Terapêutica.

\section{Resumen}

Antecedentes: Los procedimientos de endodoncia regenerativa, especialmente la terapia de revascularización pulpar, se han convertido en una opción real para el tratamiento de dientes permanentes inmaduros con ápices abiertos. Este tipo de abordaje salvó muchos dientes que de otro modo se habrían extraído. La técnica es sencilla y eficaz y la puede realizar cualquier odontólogo clínico. Objetivo: Este artículo tuvo como objetivo revisar la literatura para sustentar el reporte de un caso de un Procedimiento de Endodoncia Regenerativa en un paciente masculino de 12 años con ápice abierto del elemento dental inmaduro 21. Metodología: Se buscaron artículos sobre revascularización pulpar para obtener la formación completa de las raíces. Se realizaron búsquedas en línea, cuyas bases de datos incluyen BVS / BIREME, Web of Science, PUBMED Central, Science Direct, Coordinator for the Improvement of Higher Education Personnel (CAPES), The Cochrane Library y PROSPERO). Resultados: Los artículos investigados mostraron que los Procedimientos de Endodoncia Regenerativa son eficientes para estimular la formación de la porción terminal de la raíz. El caso descrito es consistente con los resultados ofrecidos por los artículos, mostrando un diente apical abierto inmaduro que tenía su punta radicular completamente formada luego de la terapia de revascularización pulpar. Conclusión: La terapia de revascularización pulpar es un tratamiento eficaz y práctico para dientes inmaduros con ápices abiertos.

Palabras clave: Endodoncia; Hidróxido de calcio; Vasos sanguíneos; MTA; Células madre; Terapéutica.

\section{Introduction}

Immature teeth with unfinished apices are commonly found in routine endodontic clinics. Nearly fifteen years ago, the only way to treat these teeth would be through stimulated apexification, carried out with products based on calcium hydroxide in order to form a squared shaped apice, which left as a result thin walls that would easily fracture under stress.

Although there have been previous experiments trying to stimulate apical closure, it was only in 2004 that Banchs and Trope(Banchs et al.,2015) presented Pulp Revascularization Therapy (PRT), which according to their experiments would be able to help finish the apical formation of immature teeth whose apices had not been finished. In that time little was known about the role of oral stem cells in the process, and the cells responsible for hard tissue deposition were thought to be undifferentiated mesenchymal cells present in the periodontal ligament (Shah et al., 2008).

The mechanism responsible for hard tissue formation in the periapical area remains largely unknown, but as researches evolve the main aspects of this complex process become progressively clear. Blood influx is essential for its beginning and development, for the simple fact that all the nutrients and cell reservoir come from it. The second most important factor is the absence of infection within the root canal space. Bacterial or fungi presence may jeopardize any attempt of mineralized tissue deposition, due to the byproducts left as a consequence of diapedesis and phagocytosis, which stimulate clastic cells responsible for the destruction of the mineralized tissues. The third most important factor is a material that would simultaneously induce hard tissue formation and decrease microbial proliferation. The materials categorized for so are the bioceramics, whose most studied material is MTA.

Last but not least, stem cells associated with traditional differentiated cells such as fibroblasts and osteoblasts, located in the periapical region, are then able to repair damages caused by previous infections and finish apical formation. The aim of this article is to report a case of apical formation of a 13-year-old male patient who needed root canal therapy to finish root formation, and revise the literature concerning hard tissue mineralization. 


\section{Literature review}

\section{Immunological aspects of hard tissue formation}

Mammals belong to a category of most developed and complex living beings. Their biology depends on blood healing and a number of differentiated and undifferentiated cell interactions in order to reach homeostasis (Trowbridge et al.,1997). Tissue neoformation and bone turnover are necessary steps to repair wounds; and any pathology that interfere in the proper balance of these factors will jeopardize or even halt the possibility of healing, leading to dysfunctions, increasing life risks(Clark,1996).

After having been injured, the damaged tissues unleash specific substances that act locally but may also stimulate the formation and recruitment of different cell types, depending on the organic needs and sites of inflammation(Schroder,2000). The substances responsible for leucocytes communication are the cytokines and low molecular compounds originated from the damaged cells, such as histamine (Stashenko,1990). The cytokine family is vast, with synergistic and antagonistic functions, which modulate inflammation. It includes Interleukins (IL), Chemokines (CKs), Interferon (IFN), Tumor Necrosis Factor (TNF), Coloning-stimulating Factor (CSF), and Growth Factor (GF). Together they interact and promote damage repair by activating chemotaxis (Yoshimura et al., 1987).

Damaged tissues usually triggers vascular alterations, initially to contain hemorrhage, and then to start up healing mechanisms. Right after an injury, cytokines liberated from cell degranulation, such as platelets, lead to the activation of both kinds of immunities: innate and adaptive (Chaplin, 2003). This classification is merely didactical, because their interaction is so connected that, in practical terms, they act as one.

Periapical tissues play fundamental roles in the endodontic field for being able to contain bacterial invasion once the dental pulp is destroyed. Finding periapical lesions in immature permanent teeth with open apices is a situation commonly found in routine examinations in almost all specialities in dentistry. This offers peculiar problems for endodontists when they have to obturate the root canals. The unstimulated thin dentin walls in this case leave behind a fragile tooth unable to support mastication stresses, or even support radicular dental posts due to fracture risks (Andreasen et al., 2006).

In order to finish root formation and assure its integrity, Regenerative Endodontic Procedures (REPs) were researched and developed, allowing the completion of the apice, forming a better structured tooth with blood circulation where, otherwise, there wouldn't be any(American Association of Endodontists,2016).

Pulp revascularization for apical formation is accomplished with endodontic files, intentionally introduced into the unfinished open apice to cause bleeding, usually accomplished with K-files. The basis for mineralized tissue formation is the absence of infection, along with induced controlled injury and the blood clot formation. For so, the chosen file is inserted 2 $\mathrm{mm}$ straight into the open apice; in order to cause bleeding visually observed flowing from the root canal space. Afterwards, clot formation will take place, ranging from 4 to eight minutes in humans. In this sense, eight to ten minutes in average in the minimum time period for clot formation within the root canal. The induced bleeding will be responsible for arterial blood influx necessary to bring the necessary nutrients and cell arsenal into the periapical area, especially when there is presence of apical lesions. The blood flow will end up invading the canal space and reestablishing circulation through the gaps of the open apice. The larger the opening, the best the chances for mineralization (Murray et al., 2007).

After the clot is formed, it forms a kind of physical barrier against pathogens and foreign bodies, providing matrix for the income and deposition of different sort of cell types involved in the process: traditional cells such as fibroblasts and specialized oral stem cells in the surrounding periodontal tissues, which will work as growth stimulators in the healing process. Therefore, the induced injury is the most important step for the release of inflammatory mediators, especially interleukins present in the disrupted vessels. Once the arterial capillaries are injured, platelet liberation will start the cascade responsible for 
clot formation, composed mainly of cross linked fibrin mixed with extracellular matrix proteins, whose main representatives are fibronectin, thrombospondin and vitronectin (ActaOdontolScand, 1961; Martin, 1997).

The scientific literature is replete of histological experiments regarding regenerative endodontic procedures, most of them accomplished in immature teeth with open apices, with and without periapical lesions. Many of such studies began in animal models, proceeding later to experiments in humans. After scrutinizing the results, what could be histologically observed in the periapical area was cementum-like and bone-like mineralized tissues present in the end of the newly formed periapical area. Fibrous connective tissue similar to the periodontal ligament was also observed (Becerra et al., 2014; Lei et al., 2015).

The periapical area, unlike the dental pulp which is limited by inextensive dentin walls, has ample capacity of effective immune response. After the initial inflammatory response caused by the insertion of the file into the periapical area, there is an invasion of reparative cells. The first cell type to arrive in the site are the neutrophils, and it happens within minutes. They are the main representatives of the innate immunity, phagocyting nonself and foreign bodies, including microbial lifeforms. The second and most representative of the innate immunity, making a link with specialized sophisticated cell forms, are the monocytes/macrophages. They are antigen presenting cells (APCs) responsible for the exhibition of protein fragments of the antigens to the lymphocyte lineages (specific subsets of $\mathrm{T}$ cells and $\mathrm{B}$ cells), integrating the innate and adaptive immunities (Martin,1997). In this sense, the inflammation caused by the induced controlled injury will be responsible for the initial sore sensation of dental extrusion due to the edema caused by the local vascular alterations. What comes afterwards is a reparative process, rather than a regenerative one (Trowbridge et al., 1997; Cymerman et al.,1984).

For the next stage, new blood vessel formation is necessary to bring the nutrients and furnish the cellular diversity necessary for mineralization. This integration of different sorts of cells will be the key for apical closure.

\section{Vascular events}

Blood supply is the most important event for reaching mineralization in mammals. The periapical region is rich in cellular diversity that needs nutrients for integration and metabolism for rearrangements of soft and hard tissues affected by injuries. In this sense, two processes are expected for apice closure: vasculogenesis and angiogenesis(Carmeliet et al.,2000). The former can be defined as vessel formation that takes place during the embryonic period (Hanahan et al.,1996), while the latter is the formation from pre-existing capillaries that is usually triggered by different sorts of traumas inflicted in determined area of the organism in question, every time it is necessary and, naturally as it seems, when the organism is able to produce it.(Chain et al.,2004).

Revascularization techniques was put into practice with the aim of stimulating immune reaction to an injury, intentionally accomplished. It induces sequence of inflammatory events that unleash blood elements, which in turn activate thrombus formation, granulation tissue organization, fibroblast proliferation and matrix accumulation. When this complex architecture is formed, cell proliferation will take place, resulting in newly formed capillary formation consisting mainly of endothelial cells (Nicoli, 2015).

This repairing tissue will require a considerable amount of oxygen for the organic cellular needs. For so, angiogenesis will be stimulated and regulated by growth factors and pro-angiogenic cytokines and neovascularization inhibitors (Klagsbrun et al., 1991). This complex cascade will be simultaneously regulated by stimulatory cells, liberating growth factors, while inhibitory cells will counterbalance by producing interferons, proteolytic fragments, interleukins, and protease inhibitors (Tomanek et al., 2000; Klagsbrun et al., 1991). 


\section{The anatomy and physiology of the apical area}

The apical area can be defined as the apical portion of the teeth. Naturally, it involves not only the dental apice but also the alveolar bone and periodontal ligament, comprising the apical canal as well as the apical foramen with all its branches defined as the apical deltas or foraminas. There is also the presence of accessory and secondary canals that are usually located within the 3-4 mm of the radicular apice (Molander et al., 1995; Takahashi et al., 1982). Unlike the dental pulp which is limited by inextensive dentin walls, the apical area can respond much more effectively with immune-modulated cells regulated by cytokines and interleukins, that will be responsible for inhibitory or stimulatory effects.

The process begins with veins carrying venous blood from terminal portion of root canal space, poor in oxygen and nutrients, while the afferent arteries penetrate this open space, demarcated from the main dental artery. Afterwards, the central arteriole penetrate the apical portion and is subdivided in small branches, called meta-arterioles and precapillaries, as far as the location of the bioceramic inserted into to medium third of the tooth. This integration constitutes the capillary bed, responsible for the exchange of nutrients in the open apice site of immature teeth (Kishi et al., 1989).

The dental apice undergoes high mastication pressures even in normal conditions. The stress applied over the teeth makes the periapical area be constantly renewed due to bone turnover activity and increased blood circulation (Jung et al., 2008). In this sense, the materials inserted within this area will be determinant for apice closure.

\section{Bioceramic considerations}

Bioceramics can be defined as bioglasses, or ceramic material that can be applied in more developed organisms such as mammals for being biocompatible (P. et al.,1984). Their ceramic oxides, inert to the organism and resorbable, will eventually be surrogated by immunocompetent cells after they have assisted healing (J. F.,1999; Oonishi,1988).

From all the Bioceramics used in endodontics, MTA has been the most researched. It was firstly developed to be used as a dental root repair material by Mahmoud Torabinejad, who researched and altered Portland cement used in civil construction, by incorporating bismuth oxide powder for radioopacity. It appeared in the early nineties, and has been used in the present days with outstanding clinical results.

MTA is inserted into the root canal space as a stimulatory material for a number of procedures such as for creating apical plugs during apexification, repairing root perforations, or even for root canal therapy, treating internal root resorptions. It can be used as a root-end filling material and as pulp capping material. Originally, it was offered in the market in dark gray in color, although white versions have also been offered since 2002.

Before the appearance of MTA in endodontics, many clinical situations had much less probabilities to be solved, increasing the numbers of dental extractions all over the world. Its alkalinity associated with its capability to stimulate neoformation of osteoid tissue formation made it perfect to solve situations such as perforations and trepanations so common in the endodontic treatment(Torabinejad et al.,1993; Torabinejad et al.,1994). It has two basic clinical formulations: a white or gray powder composed of fine hydrophilic particles. Its main components are tricalcium silicate, tricalcium aluminate, tricalcium oxide and silicate oxide. There are also small amounts of other mineral oxides responsible for the physical and chemical properties of the aggregate, such as bismuth oxide, responsible for its radiopacity (Torabinejad et al.,1994).

Among its main clinical indications, MTA has been used for clinical situations such as: direct pulp capping (Schwartz et al.,199), pulpotomies (Tziafas et al.,2002; Soares et al.,1996) internal and external root resorptions (Menezes et al.,2004), cervical plugs (Hsien et al.,2003), apical plug in immature teeth with open apices (Mah et al.,2003), root canal filling(Witherspoon et al.,2001) and, in 2006, began to be used as an intra-radicular reinforcement of teeth with incomplete rhizogenesis (Holland et al.,1999). Its main characteristics are the pH of 10.2, which rises to 12.5 after nearly 3 hours, 
remaining steady after this period. Current literature affirms that the final setting time for ProRoot MTA ranges from 45 and 140 min (Andreasen et al.,2006) Aditionally, it shows adequate sealing properties in in vitro studies.

From all that was mentioned above, MTA is usually the first choice due to its being researched for nearly thirty years in clinical situations and experiments. Due to these facts it was used in the case report of this work.

\section{Apical closure dependent of stem cell activity}

Apical closure depends not only on the arrival of appropriate blood influx and traditional cell activity, such as fibroblasts and osteoblast. It depends also on the role of oral stem cells that allows the finalization of the apical third of teeth with open apices.

In average, three basic kinds of stem cells have been described to play important roles in the closure of open apices. They are: Dental Pulp Stem Cells (DPSCs), Periodontal Ligament Stem Cells (PDLSCs) and Stem Cells from Apical Papilla (SCAPs). Although stem cells from the alveolar bone have also been cited (Rodan, 1992; Kotaru et al.,2014)

The first sort of stem cells to be discovered and used in experiments were the DPSCs. The determinant reason for this fact is that dental pulps can be collected without many efforts, from extracted teeth due to a number of reasons such as orthodontics and untreated dental cavities. These cells are more likely to produce neurons than other stem cells, demanding fewer ethical matters and with the possibility of being easily isolated and cultivated. DPSCs are able to differentiate into osteoblasts, endothelial cells, odontoblasts and fibroblasts, provided they are given the due growth factor in vitro. More interestingly yet, in vivo, they can produce adult mature bone showing Havers canals with adequate blood influx. Finally and expectable as it seems, they can form dentin-like mineralized tissues (Windley W et al., 2005). Therefore, their role seems to be fundamental for helping closing open immature apices (L.H. Chueh et al., 2005).

Apical closure involves, in essence, stem cells for the dental pulp and also those from the periodontal ligament (PDL). Therefore, Periodontal Ligament Stem Cells (PDLSCs) have also been cited as the type of cell responsible for the biological frame of the dental apice. Their diversification is described by works such as the one described by Kook at al. (Wang L et al., 2011), who suggest that they can indeed produce cementum/PDL-like tissue in vivo. On the other hand, in vitro, they seem to differentiate into osteoblasts, cementoblasts, and adipocytes.

Finally, the apical papilla has also been cited by some authors as the third kind of cells with pertinent role in the finishing of open apice teeth. They are able to differentiate into osteoblasts, odontoblasts and adipocytes in vitro, while in vivo they also differentiate into osteoblasts. Altogether, these three kinds of oral stem cells present in the apical region serve as a sort of cell storage, able to be triggered to produce hard functional tissues (Jeremy J Mao, 2008).

\section{Case Report}

Twelve-year-old male patient GHPB, searched for the dental assistance of Faculdade de Odontologia do Recife. His mother reported impact trauma 2 years before, which fractured the middle third of the crown of tooth 21 (Figure 1). 
Figure 1: Impact trauma inflicted over the crown of tooth 21.

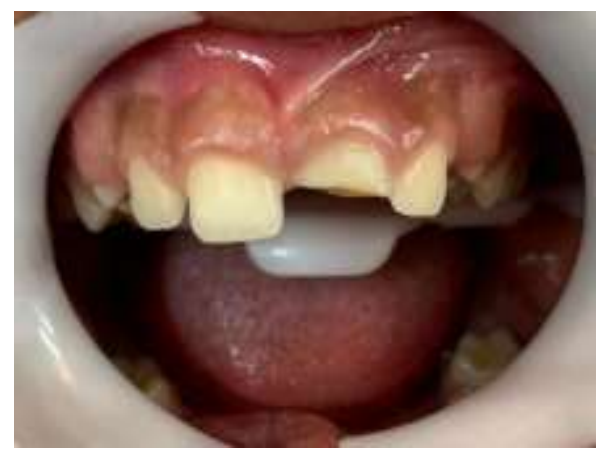

Source: Authors.

After anamnesis and clinical examination, periapical radiographs were taken and revealed an immature tooth with an open apice and an apical lesions. Figure 2.

Figure 2. Incomplete apice formation with apical lesion and middle-third crown fracture. Apical lesion could also be observed.

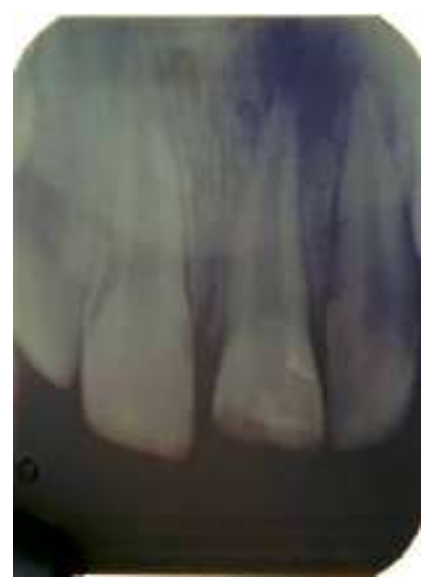

Source: Authors.

Due to the age, pulp revascularization therapy was thought as a treatment plan. The patient began to be treated in September 2020, and the therapy was carried out in five sessions.

In the first appointment, coronary opening was accomplished. The root canal space was then irrigated with $2.5 \%$ sodium hypochlorite followed by odontometry. The root canal was then dried with paper points and Ultracal was softly pressed and inserted as intracanal medication, followed by the sealing of the cavity with Coltosol. Ultracal is often used because of its capacity to alkalinize the environment within the root canal, and also to stimulate osteoblastic activity.

Fifteen days later, the patient returned for consultation, for reassessment, clinical examination (palpation and percussion) and intraoral physical examination, and was free of pain or any discomfort.

A week later, the root canal was over-instrumented, and bleeding was intentionally accomplished with a K-file (80). In the process, another periapical radiograph was taken. After the first revascularization attempt, on his last visit 15 days after the procedure, the patient reported no pain or discomfort. MTA REPAIR HP was then inserted into the periapical region of the open apice, and the cervical opening was sealed with light-cured glass ionomer. Six months later, the patient returned for a follow-up visit, requiring another periapical radiograph of tooth 21 , showing a little overflow of MTA and islets of calcification in the image, with the terminal end of the root tapered, suggesting apical closure (Figure 3) 
Figure 3. MTA overflow and islets of calcification in the image, suggesting apical closure.

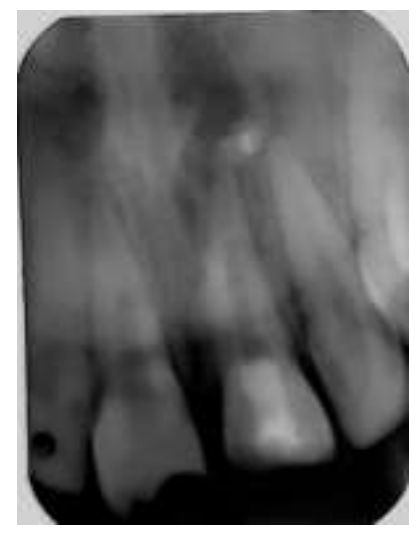

Source: Authors.

In order to accomplish a double check, cone beam tomography was requested to observe, in details, the results of the pulp regenerative procedure (Figure 4A, B and C). The root end was finished, and the apical canal space was visible. Apical lesion in regression was also observed.

Figure 4 A. Cone beam tomography showing apical closure. B) Apical root canal space finished and visible and MTA overflow. C) Apical lesion in regression.
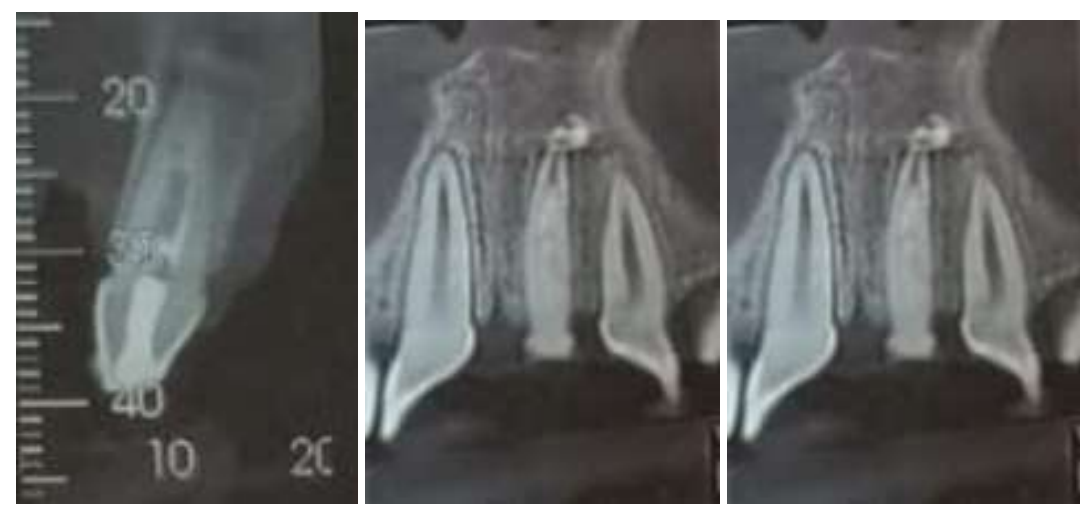

Source: Authors.

\section{Discussion}

Traumatic injuries is one of the main reasons responsible for dental emergencies; and the anterior teeth are more prone to be affected, especially for boys with ages ranging from 4 to 15 years old (Gupta S et.al.,2011; Marcenes W et al.,2001). Alterations in phonation, pronunciation and the aesthetic impact cause by the fracture of the crown made the patient look for professional assistance.

The completion of the root end formation is very important for the teeth to support the physical stress that affects them routinely. Mastication, malocclusions and even emotional stresses apply a considerable pressure that is distributed along the dental roots, and transmitted to the maxillaries. The distribution of the forces applied in the periapical area is much more well dispersed with a completely formed conic root end than otherwise.

Before the emergence of endodontic regenerative procedures, there were basically two modalities of treatment for teeth with open apices: techniques with calcium dihydroxide to stimulate the establishment of an apical mineralized barrier, which after formed were usually squared with thin dentin walls in a procedure denominated apiceogenesis; and another 
technique using MTA, to induce an artificial mineralized conic barrier, completing root formation. This is possible due to MTA capacity of alkalinization, which reduces clastic activity while triggers osteoblastic proliferation, stimulating hard tissue formation.

The insertion of MTA, in some situations, may be overextended into the periapical area. This happens because of the open apice three-dimensional disposition. Nevertheless, by using periapical radiographs, usually the first choice for traditional root canal treatments, practitioners can only observe two dimensions, being the third one able to be observed only with the use of cone beam tomography. MTA overextensions, at least theoretically, may cause no harm to the patients due to its excellent biocompatibility and alkalinity; although some level of discomfort may be present after the procedure is made. In this work, the patient reported no pain or discomfort.

Cone beam tomography showed apical closure and hints of apical lesion healing, six months after the endodontic regenerative procedure.

Open apices offer more available space for blood influx, bringing in nutrients, oxygen and immune-competent traditional cells, and enhancing angiogenesis formation. The apical framework will then be established in the absence of infection within the root canal space, and by the interactions of the traditional cells, especially fibroblasts and cells from the innate immunity such as neutrophils and antigen presenting cells such as macrophages and dendritic cells, which activate the second most sophisticated sort of immunity: the adaptive one; represented mainly by lymphocytes. Because of such peculiar biological features, MTA placement onto the induced blood clot stimulate cells to produce dense hard tissue formation when in close contact with the surrounding periapical tissues.

In this sense. the main bases of apical closure is root canal decontamination, which was made with the introduction of Ultracal, followed by induced controlled injury in the following consultation, accomplished with overextended files inserted right into the periapical area to cause bleeding. After blood clot formation, fibroblasts will begin the healing process, with the nutrients offered by blood influx. The process will be modulated by interleukins powerful enough to stimulate traditional cells to expand in number and activate other cell types such as Antigen Presenting Cells interacting with T-lymphocytes.

A pertinent work (Shimazu et al.,2012) explains that the cells present in the periapical area are categorized as fusiform cells, macrophages, fibroblasts and mesenchymal undifferentiated cells. Up to date these latter cells have been named as oral stem cells. The study concluded that it is possible to regenerate open apices of a permanent tooth with irreversible pulpitis or with periapical lesions. On the other hand, other studies affirm that the kind of immunological response varies with the type of progenitor cells modulating the healing process. In their senses, repair might be enhanced by pulp progenitor cells, and also by periodontal cells, or more predictable yet, by a combination of both cell types which are present in the periapical region. Such cells are represented by DPSCs, able to differentiate into odontoblasts or osteoblasts, characterized by producing mineralized nodules, and also by PDLSCs, finishing the periodontal membrane (About I et. al,2000; Couble ML et al.,2000), and completing dentin formation and also the sensorial tissues present in the periodontal ligament.

\section{Conclusion}

Apical closure is an easy doing procedure that can be used for the treatment of immature permanent teeth with open apices. It is also unexpensive, and can be accomplished by clinical dental professionals. Due to these characteristics, this procedure may help avoid dental extractions of children or teenagers, contributing to oral health maintenance all over the world. 


\section{References}

About, I., et al. Human dentin production in vitro. Exp Cel Res. 258(1):33-41.https://doi.org/10.1006/excr.2000.4909

American Association of Endodontists. AAE Clinical Considerations for a Regenerative Procedure [Internet]. American Association of Endodontists, https://www.aae.org/specialty/wpcontent/uploads/sites/2/2017/06/currentregenerativeendodonticconsiderations.pdf.

Andreasen, J. O., Munksgaard, E. C., \& Bakland, L. K. Comparison of fracture resistance in root canals of immature sheep teeth after filling with calcium hydroxide or MTA. Dent Traumatol. 22: 154-6.https://doi.org/10.1111/j.1600-9657.2006.00419.x

Banchs, F., \& Trope, M. (2004) Revascularization of immature permanent teeth with apical periodontitis: new treatment protocol? J Endod 30: 196200.https://doi.org/10.1097/00004770-200404000-00003

Becerra, P., Ricucci, D., Loghin, S., Gibbs, J. L., \& Lin, L. M. Histologic study of a human immature permanent premolar with chronic apical abscess after revascularization/revitalization. J Endod. 40(1):133-9. 10.1016/j.joen.2013.07.017 https://doi.org/10.1016/j.joen.2013.07.017

Carmeliet, P., \& Jain, R. K. (2000) Angiogenesis in cancer and other diseases. Nature 407(6801), 249-57https://doi.org/10.1038/35025220

Chain, J., Jones, M. K., \& Tarnawski, A. A. Serum response factor is a critical requirement for VEGF signaling in endothelial cells abd VEGF-induced angiogenesis. The Faseb Journal, p1-19, https://doi.org/10.1096/fj.03-1232fje

Chaplin, D. D. Overview of the immunologic response. Allergy and Clinic. Immunol., 111.

Couble, M. L., et al. Odontoblast differentiation of human dental pulp stem cells in explants culture.

Calcif Tissue Int. 2000 Feb,66(2):129-38.https://doi.org/10.1007/PL00005833

Clark, R. A. F. Wound repair. Overview and general considerations. In: The Molecular and Cellular Biology of Wound Repair (2nd ed.), edited by Clark RAF. Plenum, 3-50.

Cymerman, J. J., et al. Human T lymphocyte subpopulations in chronic periapical lesions. J Endod 10, 9-11. 1984.

Gupta S, Kumar-Jindal S, Bansal M, Singla A. Prevalence of traumatic dental injuries and role of incisal overjet and inadequate lip coverage as risk factors among 4-15 years old government school children in Baddi-Barotiwala Area, Himachal Pradesh, India. Med Oral Patol Oral Cir Bucal. 2011,16:e960-5

Hanahan, D., \& Folkman J. Patterns and merging mechanisms of the angiogenic switch during tumorigenesis. Cell, v.86, 353-364, 1996. https://doi.org/10.1016/S0092-8674(00)80108-7

Holland, R., et al. Reaction of dogs' teeth to root canal filling with mineral trioxide aggregate or a glass ionomer sealer. $J$ Endod. 1999, 25: 72830.https://doi.org/10.1016/S0099-2399(99)80118-6

Hsien, H. C., et al. Repair of perforation internal resorption with mineral trioxide aggregate: a case report. $J$ Endod. 2003, 29: 538.9.https://doi.org/10.1097/00004770-200308000-00011

Jeremy, J., M. (2008) Stem Cells and the Future of Dental Care. N Y State Dent J 74: 20-24.

J. F. Shackelford (editor) (1999) MSF bioceramics applications of ceramic and glass materials in medicine

Jung, I. Y., Lee, S. J., \& Hargreaves, K. M. Biologically based treatment of immature permanent teeth with pulpal necrosis: a case series. J Endod. 2008. 34(7):876-87. 10.1016/j.joen.2008.03.023.https://doi.org/10.1016/j.joen.2008.03.023

Kishi, Y., et al. Vascular architecture of the pulp in human teeth using resin cast examined under SEM. Jap J Oral Biol 1989,31:112114.https://doi.org/10.2330/joralbiosci1965.31.112

Klagsbrun, M., \& D’Amore, P. A. (1991) Regulators of angiogenesis. Ann. Rev. Physiol. 53, 217-239. https://doi.org/10.1146/annurev.ph.53.030191.001245

Kotaro, S., et al. Allogenic tooth transplantation inhibits the maintenance of dental pulp stem/progenitor cells in mice. Springer-Verlag Berlin Heidelberg. 2014. https://doi.org/10.1007/s00441-014-1818-8

Lei, L., Chen, Y., Zhou, R., Huang, X., \& Cai Z. Histologic and immunohistochemical findings of a human immature permanent tooth with apical periodontitis after regenerative endodontic treatment. J Endod. 41(7):1172-9. 10.1016/j.joen.2015.03.012 [PubMed] [CrossRef].https://doi.org/10.1016/j.joen.2015.03.012

L. H. Chueh, G. Huang. Immature teeth with periradicular periodontitis or abscess undergoing apiceogenesis: a paradigm shift. $J$ Endod, 32 (2006), 12051213.https://doi.org/10.1016/j.joen.2006.07.010

Marcenes, W., \& Murray, S. Social deprivation and traumatic dental injuries among 14-year-old schoolchildren in Newham, London. Dent Traumatol. 17:1721.https://doi.org/10.1034/j.1600-9657.2001.170104.X

Mah, T, et al. Periapical inflammation affecting coronally-inoculated dog teeth with root fillings augmented by white MTA orifice plugs. $J$ Endod. 29: 4426.https://doi.org/10.1097/00004770-200307000-00004

Martin, P. Wound healing_aiming for perfect skin regeneration.Science276: 75-81, 1997. 10.1126/science.276.5309.75

Menezes, R, et al. Histologic evaluation of pulpotomies in dog using two types of mineral trioxide aggregate and regular and White Portland cements as wound dressings. Oral Surg Oral Med Oral Pathol Oral RadiolEndod. 2004, 98: 376-9.https://doi.org/10.1016/j.tripleo.2004.03.008 
Molander, B., et al. Panoramic and restrictive intraoral radiography in comprehensive oral radiographic diagnosis. Eur J Oral Sci. 103(4):191-198. https://doi.org/10.1111/j.1600-0722.1995.tb00159.x

Murray, P. E., Garcia-Godoy, F., \& Hargreaves, K. M. Regenerative endodontics: a review of current status and a call for action. J Endod 2007, 33(4): 37790.https://doi.org/10.1016/j.joen.2006.09.013

Nicoli, N. V. V. Regenerative Endodontics: advances in endodontic therapy. FOL • Faculdade de Odontologia de Lins/Unimep 2015, 25(2): 74-5

Oonishi, H. Aoki, K. Sawai (editors) (1988) Bioceramics.

P. Ducheyne, G. W. Hastings (editors) (1984) CRC metal and ceramic biomaterials.

Rodan, G. A. Introduction to bone biology. Bone 13 Suppl 1, S3-6.https://doi.org/10.1016/S8756-3282(09)80003-3

Schroder, J. M. Chemoattractants as mediators of neutrophilic tissue recruitment. Clin Dermatol 18:245-263. 2000.https://doi.org/10.1016/S0738081X(99)00117-0

Schwartz, R. S., et al. Mineral trioxide aggregate: a new material for endodontics. J Am Dent Assoc. 1999, 130: 96775.https://doi.org/10.14219/jada.archive.1999.0337

Shah, N, et al. Efficacy of revascularization to induce apexification/apexogensis in infected, nonvital, immature teeth: a pilot clinical study. $J$ Endod. 34(8):919-25.10.1016/j.joen.2008.05.001

Shimazu, E., et al. Histologic observation of a human immature permanent tooth with irreversible pulpitis after revascularization/regeneration procedure. $J$ Endod. 38, 1293-7, 2012.https://doi.org/10.1016/j.joen.2012.06.017

Soares, I. M. L. Resposta pulpar ao MTA - agregado de trióxido mineral -comparando ao hidróxido de cálcio em pulpotomias. Histológico em dentes de cães [Tese Professor Titular]. Florianópolis: Universidade Federal de Santa Catarina, 1996.

Stashenko, P. Role of immune cytokines in the pathogenesis of periapical lesions. Endod Dent Traumatol 6, 89-96. 1990.https://doi.org/10.1111/j.16009657.1990.tb00400.x

Takahashi, K., Kishi, Y., \& Kim S. A scanning electron microscope study of the blood vessels of dog pulp using corrosion resin casts. $J$ Endod,8:131135.https://doi.org/10.1016/S0099-2399(82)80249-5

The role of the blood clot in endodontic therapy. An experimental histologic study. ActaOdontolScand1961, 19: 324-353.

Torabinejad, M., et al. Dye leakage of four root end filling materials: effects of blood contamination. $J$ Endod. 20:159-63.https://doi.org/10.1016/S0099$2399(06) 80326-2$

Torabinejad M, et al. Sealing ability of an MTA when used as a root end filling material. $J$ Endod. 19: 591-5. https://doi.org/10.1016/S0099-2399(06)80271-2

Trowbridge, H. O., \& Emling, R. C. Inflammation. A Review of the Process (5th ed). Quintessence Publishing Co, Carol Stream, Illinois. 1997.

Tziafas D, et al. The dentinogenic effect of mineral trioxide aggregate (MTA) in short-term capping experiments. IntEndod J. 35: 24554https://doi.org/10.1046/j.1365-2591.2002.00471.x

Wang L, et al. Characterization of stem cells from alveolar periodontal ligament. Tissue Eng Part A 2011, 17(7-8): 1015-26. [http://dx.doi.org/10.1089/ten.tea.2010.0140] [PMID: 21186958

Windley W, et al. Disinfection of immature teeth with a triple antibiotic paste. J Endod, 31 (2005), 439443.https://doi.org/10.1097/01.don.0000148143.80283.ea

Witherspoon, D., \& Ham K. One-visit apexification: Technique for inducing root end barrier formation in apical closures. PractProcedAesthet Dent. 13: 45560

Yoshimura, T., et al. Purification of a human monocyte-derived neutrophil chemotactic factor that has peptide sequence similarity to other host defense cytokines. Proc Natl Acad Sci USA 84:9233-9237. 1987https://doi.org/10.1073/pnas.84.24.9233 